\title{
Studies on Plasticity Laws of Polycrystalline Metals at Elevated Temperatures
}

(Specially on the Effects of Hydrostatic Stress and Strain History)

by

\section{Masateru OHNAMI}

(Faculty of Science and Engineering, Ritsumeikan University, Kyoto)

and Katsuhiko MoToIE

(Hiroshima Denki University, Hiroshima)

\section{1 は しがき}

最近における材料強度拈よび材料の塑性加工の分野 飞扮ける数值計算技術和よび実験技術の急速な発展と かかわって, 金属材料の塑性拉よび破壞法則に従来の 塑性理論を適用するらえでの限界性を明らかにすると 同時に, より適切な塑性法則拈よび破壊法則の確立を めざすための研究の必要性が著しく高かまってきてい ると思われる。すなわち, 一つは, 切欠きやき裂材な どの複雑な材料形状やクラックの進展状況からくる多 軸応力下の弾塑性応力解析が大変形（有限ひずみ）を 含めて有限要素法などの高速電子計算の運用汇より飛 躍的溶易になりつつ岁ることとかかわって, より確 かな塑性法則や破壞法則の定式化が強く望委礼ている ことである.二つつ, 最近に抢ける各種のX線回折技 術, 高性能の電子顕微鏡扒よび高静水圧力下の材料強 度試験技術などの開発を通じて, 材料の塑性変形と破 壞について新しい実験的検証の側面が開かれ，その結 果, 微視的立場での塑性変形 (Microplasticity) や格 子久陥を含む材料空間を刘象とする塑性変形に関する 一般連続体の力学 (Mechanics of generalized continua) 飞対して従来の微小変形に対象する塑性力学 の限界性が指摘されてきたことである。ここでは, 議 論の容易のため対象とする材料を熱的に比較的安定な 多結晶の純金属抢よび低炭素鋼に限定し, 高温におけ る塑性法則拉よび破壊法則の定式化のう爷で当面話題

* 原稿受理 昭和45年11月 9 日

** 正 会 員 立命館大学理工学部 京都市北区等持院北町

*** 正会員広島電機大学 広島県安芸郡頖野川町
の多い静水圧応力括よびひずみ履歴の影響を中心とし て最近に执研究の展望を述べてみることにする。

金属材料の塑性加工の研究とかかわ力て, 破断条件 式清水圧応力㧍よびひずみ履歴を主要な因子として 導入することはすで古くから試みられているが，高 温クリープを含む塑性流動応力におよ涪す静水圧応力 の影響掞よびそれとひずみ履歴の影響との相互関連に ついての定式化の試みが行なわれたのは比較的最近の ことである・とくに, 高温クリープ拈よびその破壞に およぼす静水圧応力の影響が大きな矛盾なく定量化さ れたのはごく最近のことである。歴史的とみて，各種 の機械構造要素（たと党ば，内圧円管や回転円板な ぞ）を対象とする高温クリープの解析結果と実験結果 とが必らずしも一致しない理由として，(1)ひずみ履歴 の影響 (ひずみ経路の影響, creep recovery, thermal

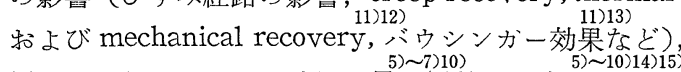
(2)塑性的体積不変則の適用限界, (3)静水圧応力成分の 影響, (4)降伏条件と流れの式の適用限界などの諸因子 が指摘され, 各個別現象の物理研究および解析研究に かなりの成果が光られたと思われる。しかしながら， これらの効果はそれぞれ独立のものではなく，互いに 関連し合ったものであることを考光るとき，この関連 性についての充分な知見がえられていないことは，高 温に打ける塑性変形打よび破壞法則の定式化を困難に している要因の一つであると思われる。したがって， 以下の論説では, 静水圧応力拈よびひずみ履歴の影響 を復合した形で現象をとら光るのではなくてできるだ けこれらを分離することにつとめ, とりわけひずみ履 
歴の影響を除去した状態での静水圧応力の影響を中心 として述べ，その5亲にたって相互の関連性について 述べることにする．な㧍，静水圧応力成分が固定拈よ び変動する場合の多軸応力状態でのひずみ履歴の影響 については紙面の関係上割愛する。また，ひずみはと くにことわらないかぎり弾性ひずみ（クリープでは瞬 間ひずみ）を含めた全ひずみとし，かつ対数ひずみの 定義によった，さらに，応力およびひずみの解析的表 示はテンソルの表示によった。

\section{2 静水圧応力による塑性的体積変化と材料の構造 変化}

巨視的あるいは統計的に等質等方性の挙動をする多 結晶金属材料に静水圧力あるい:静水圧力引張りのよ うな等方応力のみが作用するとさ，実際には材料内に 局所的な不均一性をもつので，永久的な体積変化はご く小さいるのであるにせよ，本質的には等方応力の影 響が存在するものと考光られる。事実, 多結晶 $\mathrm{Cd}, \mathrm{Zn}$, $\mathrm{Bi}, \mathrm{Sn}, \mathrm{Zr}, \mathrm{Mg}, \mathrm{Cu}, \mathrm{Fe}$ に 26000 bars までの静 水圧力を負荷するとき $\mathrm{Cd}, \mathrm{Zn}, \mathrm{Bi}, \mathrm{Sn}$ の結晶粒界 近傍で結晶粒界移動, すべり, 多重すべり, あるいは 双晶などの形で局部的な塑性流動が誘起されることが 観察されて和り，その原因として結晶軸方向による圧 縮率の差違や炭化物などの第 2 相とマトリックス間の 圧縮率の相違が挙げられている。 Fig. 1 1 は結晶の圧縮

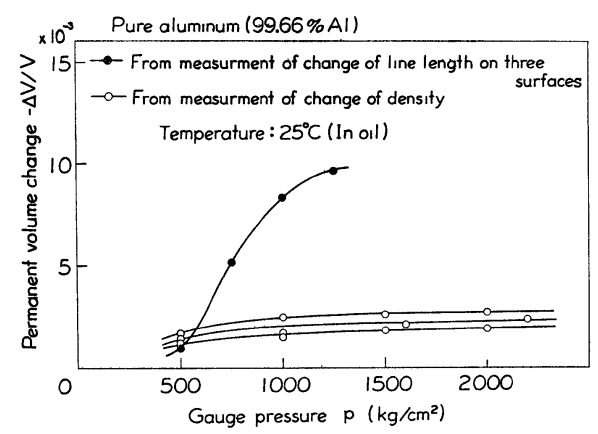

F1g. 1. Permanent volume change of pure polycrystalline aluminum under hydrostatic pressure.

率の相違のない面心立方格子の純アルミニウム(99.66 $\% \mathrm{~A} 1,360^{\circ} \mathrm{C}$ で1時間真空焼なまし) に対する液圧 処理 (Pressure soaking と呼ぶ) による密度変化を 計測した結果であり，わずかではあるが塑性的体積変 化がみられ, 同様のことが油焼した SCM 22 につい てもみられる. 静水圧力によるこのような材料の収縮 は，材料に熱平衡的に潜在的に存在する vacancy, void, cavity などの材料内の空げきが収縮するため に生じたものと思われる。

このように結晶異方性，あるいは各種の空げきをも つ多結晶金属材料にあっては, 静水圧力による材料の 構造变化がなんらかの形でつねに起こるので, 以下に
述べる降伏条件における静水圧応力の寄与については, まず一つには材料の構造変化を挙げることができよ5。 二つは, 塑性変形の主機構としてのすべりに垂直応力 成分が関与しないという保証はないので，これを考慮 する立場からも静水圧応力の寄与を論ずることがでさ よ5.な拈, 静水圧応力場に打いて材料内の空げきの 収縮を誘起する限界圧力 $p_{c}$ は，たと空ば空げきを球 としてェネルギの不安定条件から Fig. 2 の解析例のよ らに示すことができ， $p_{c}$ は材料の綎弾性係数 $E$ 打よび 表面エネルギTに依存するが，材料間の $E$ 拉よびTの 変動を考慮しても执と $p_{c}$ がほぼある一定值をとる ことは注目されてよい。したがって，このような $p_{c}$ 以上の静水圧応力の負荷状態においては上述の材料の 構造変化が考慮されなければならないだろう。

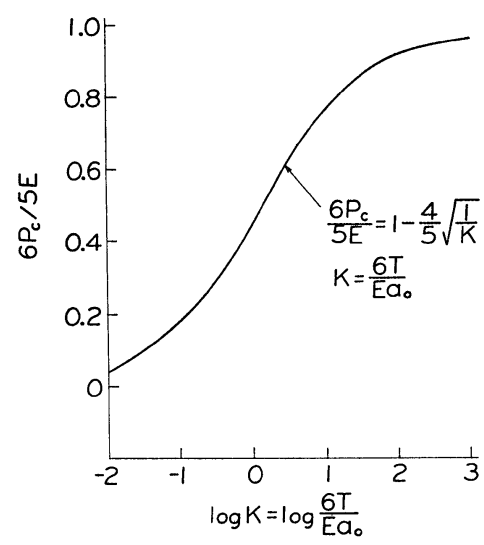

F1g. 2. Critical pressure at which cavity in material matrix collapses.

\section{3 塑性流動応力におよぼす静水圧応力の影響} 降伏関数 $f$ に打けるひずみ履歴の影響は後で述べる としていまこれを除外すると，いわゆる等方性材料の 降伏条件は応力 $\sigma_{\imath j}$ の三つの不变量を用いて

$$
f\left(J_{1}, J_{2}, J_{3}\right)=F=\text { 一定 }
$$

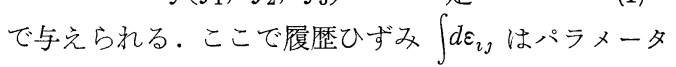
Fに含まれるにすぎない。いま, 理想塑性体を考光, 降伏曲線が変形の進行する間相以にたもたれ, かつ硬 化状態は全塑性仕事 $W_{p}$ のみに関係すると(1)式は次式 で与えられる。

$$
\begin{gathered}
f\left(J_{2}{ }^{\prime}, J_{3}{ }^{\prime}\right)=F\left(W_{p}\right) \\
\text { ここで, } \quad W_{p}=\int \sigma_{\imath \jmath} d \varepsilon_{\imath \jmath}{ }^{p}=\int \sigma_{\imath \jmath}\left(d \varepsilon^{\prime}{ }_{\imath \jmath}{ }^{p}+\delta_{\imath \jmath} d \varepsilon_{k k}{ }^{p}\right)=
\end{gathered}
$$
$\int \sigma_{\imath \jmath} d \varepsilon^{\prime}{ }_{1 j}{ }^{p}+\int \sigma_{k k} d \varepsilon_{k k}{ }^{p}=W_{s}+W_{v}$ を考慮すると(2)式は次 式のように表わすことができる。

$$
f\left(J_{2}{ }^{\prime}, J_{3}{ }^{\prime}\right)=F\left(W_{s}\right)=F\left(W_{p}-W_{v}\right)
$$

ここで $d \varepsilon_{\imath \jmath}{ }^{p}$ は塑性ひずみ増分, $d \varepsilon_{\imath \jmath}{ }^{p}$ は塑性偏差ひ ずみ増分， $W_{s}$ はすべりに費されるエネルギ， $W_{v}$ は 体積変化に費されるエネルギであり，すでに述べたよ 
うに理想材料では $W_{v}=0$ であるが高静水圧力場にあ る多結晶金属材料などでは必らずしも $W_{v}=0$ とはな らない.ゆ光に, (3)式はさらに

$$
f\left(J_{2}{ }^{\prime}, J_{3}{ }^{\prime}\right)=F\left(J_{1}, \int d \varepsilon_{\imath \jmath}\right)
$$

と書くことができるだろう．ここで $F\left(J_{1}, \int d \varepsilon_{\imath \jmath}\right)$ は 静水圧応力拉よび履歴ひずみの実験的関数であるため, 静水圧力重宣下に和沙る引張りあるいは単純ねじり実 験などの結果を包括したうえで決められる必要があり， とくに破断に至るまでの広い領域に就ける塑性変形に ついては $J_{1}$ と $\int d \varepsilon_{\imath っ}$ との相互関連から考えて $J_{1}$ の 項は無視することがでさない． Fig. 3 は，これまで若 干の研究者によってて報告されてきた静水圧力下での 静的引張りあるいはねじり実験結結果を示し, 一般的 に八面体せん断応力 $\tau_{\text {oct }}$ は負の八面体垂直応力 $\sigma_{o c t}$ の増大にともない大きくなる傾向にある. しかし, こ れだけから降伏曲線の静水圧応力に対する幾何学的形 状を決定することは困難であり，そのためには $\sigma_{\text {oct }}$ の $\tau_{o c t}$ への依存性が $\sigma_{o c t}$ の正負でどうなるかを三軸応力 実験を通じて決められなければならない。

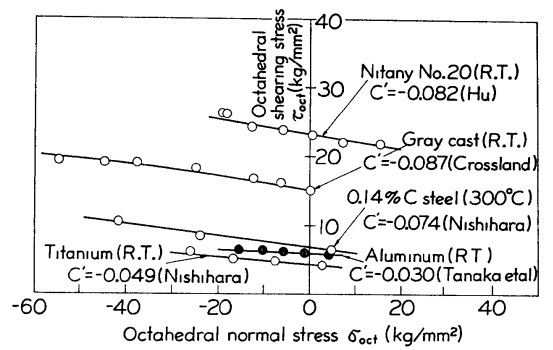

Fig. 3. Effect of hydrostatic stress on plastic yielding of several metals.

降伏条件に $J_{1}$ を考慮する試みは歴史的に種々と試 みられ, 近年では Hu が Mises の線に沿って

$$
f\left(J_{2}, J_{3}\right)=F\left(J_{1}\right), \quad F\left(J_{1}\right)=\sum_{i=1}^{\infty} a_{\imath} J_{1}^{\imath}
$$

が成り立つとし，さらに具体的には

$$
J_{2}^{\prime}=k^{2}+\alpha J_{1}+\beta J_{1}^{2}
$$

と沶き, 多軸応力問題にこれらを適用してその妥当性 を論じている。いま， $\sigma_{o c t}>0$ での厳密な議論はせず， 括もに $\sigma_{o c t}<0$ の広範团な領域に和ける挙動に注目す るかぎり，(4)式の具体的な形として

$$
J_{2}^{\prime}=k\left(k^{2}+k C J_{1}+D J_{1}{ }^{2}\right)^{1 / 2}
$$

を採用することができる。ここで $k$ は $\int d \varepsilon_{\imath っ}$ に伴って 単調に増加する正の変数で, 実際には応力の次元をも

*1 普通, 塑性理論ていう $F=$ 一定（したがって， $J_{1}$ の項は無視す る)の降伏条件は，理想材料のみならず多結晶金属材料について 屯少なくと屯初期降伏の場合充分成立する.19)

*2 歴史的には, Huber (1940), Mises および Schle1cher (1926) らによって始められ，とくに Mises (1949) は(1) 式の $f$ と して $J_{2}^{\prime}$ を， $F を J_{1}$ の任意関数でおきかえて “放物線的”降伏 限度として紹介している.19)
ち, 大気圧下での単純ねじりの任意のひずみ状態にお 今る降伏応力 $\tau_{e}$ に等しい。 また，CおよびDは材料 の降伏強度におよぼすパラメータ（スカラー）で，お そらく $\int d \varepsilon_{\imath \jmath}$, 温度 $T$ の関数でもある.なお, $C, D$ は大気圧下の多軸応力組合せ試験を通じて $\int d \varepsilon_{\imath}$ との 関連で評価できないこともないが，やはり静水圧力を 種々に変化させた静水圧力重畳下の引張りあるいはね じり試験を行なって係数を決定する方が， $\varepsilon=\int d \varepsilon_{\imath, と}$ することができ, 真の静水圧応力の影響のみを分離抽 出できて力学的挙動をは握するうえで都合がよい.

Fig. 4 は, 降伏条件に静水圧応力を考慮した場合に ついて $\tau_{\text {oct }}$ の $\sigma_{\text {oct }}$ 依存性を示与解析例であり, 図中 の $C^{\prime}$ は $C^{2}=4 D^{* 3}$ 扰よび $C^{\prime}=C / 2$ と利いた場合，す なわら降伏条件が

$$
J_{2}^{\prime}=k\left(k+C^{\prime} J_{1}\right)
$$

で表わされる場合の圧力効果の係数を示す.さきに述 べたFig. 3 の実線は各実験に一致するよう C を決め ることによって(8)式から求めた計算曲線で， $C^{\prime}$ は $C^{\prime}$ １0 でかつその大いさは $10^{-1}$ 程度のオーダのもので あることがわかる。しかし，Fig. 5 に示卞静水圧力下 (圧力媒体は油) に拈汀る純亜鉛（99.91\% Zn）の常

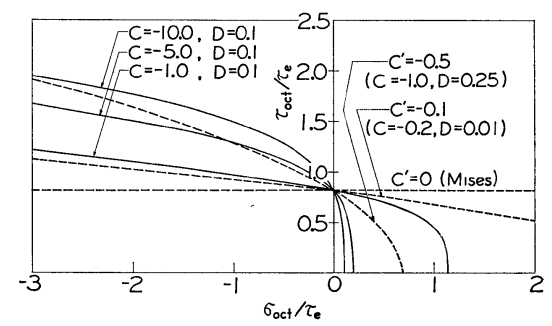

Fig. 4. Analytical representation of the effect of hydrostatic stress on flow stresses.

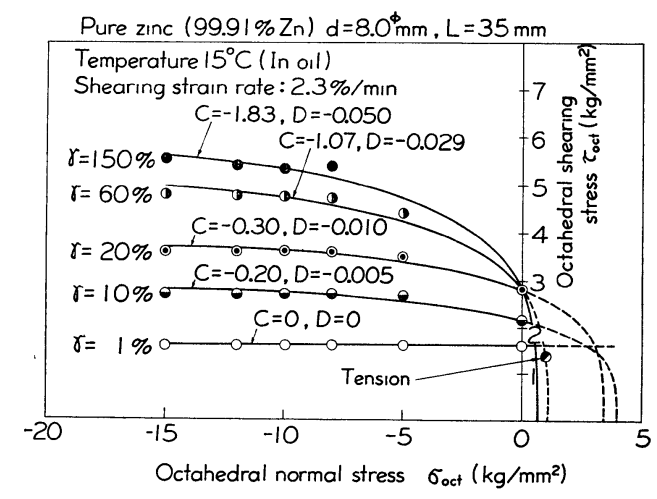

Fig. 5. Experimental representation of the effect of hydrostatic stress on the flow stresses of pure polycrystalline zinc.

*3 等 3 軸引張りて降伏あるいは破壊のおこるような上限の引張応 力が存在する之考えられるので(7)式で実際には Dの正負にかかわ らず $C^{2} \geq 4 D$ の条件が必要である. 
温静的ねじり実験結果例にみられるように， $\tau_{\text {oct }}$ に対 する $\sigma_{\text {oct }}$ の依存性はせん断ひずみての進行にともなっ て昰著になり，破断近くで大きな静水圧応力依存性を 示寸場合がある。もっとも，純アルミニウムや純鉄に ついても $C$ 打よび $D$ の数值は純亜鉛の $\gamma=50 \%$ に虰け るそれらのそれぞれ $1 / 1000 ， 1 / 10$ のオーダであるに せよ，いずれもとが大きくなるにしたがってC拉よび Dの值は単調増加する傾向をるつ。．また, Fig. 6) 6 は 静水圧力下 (圧力媒体は拡散油) 飞和战る純鉄（99.97 $\% \mathrm{Fe}$, 加工後 $900^{\circ} \mathrm{C}$ で $1 \mathrm{hr}$ 真空焼なまし) 9 の温度 $100^{\circ} \mathrm{C}$ での静的引張実験結果例を示し, Fig. 7 は は Fig. 6 の結果をFig. 5 と同様の表示法によって示したもの である。この例からわかるように, Fig. 5 亿示した常 温での結果と同様の傾向を示し，一般的に久て温度の 上昇が塑性流動応力のの減少効果をもたらすのに比べ て静水圧力は逆の効果沈もたらす傾向にあることは確 かであり,このことはたとえば以下に示す応力依存型 の速度論から容易に現象論的な説明を行ならことがで きる。

高温に抢ける塑性流動がある種の速度過程に支配さ れた変形過程であると考光てその過程の速度を支配す

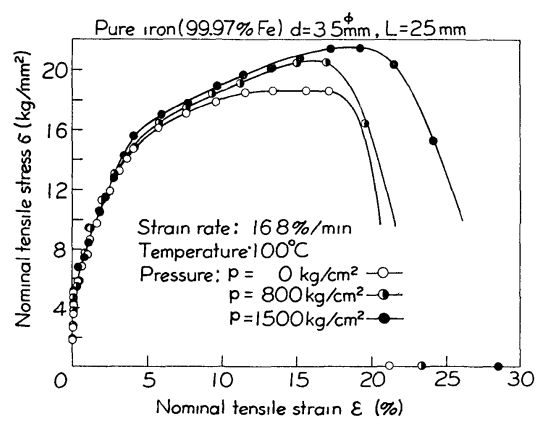

Fig. 6. Tensile stress and strain curves of pure polycrystalline iron under combined confining pressure at $100^{\circ} \mathrm{C}$.

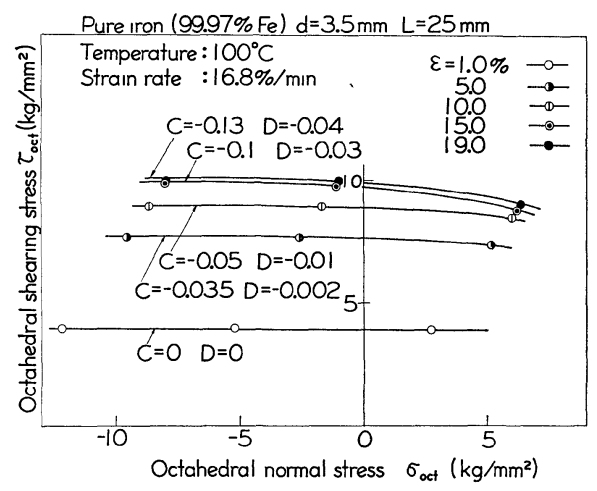

Fig. 7. Experimental representation of the effect of hydrostatic stress on the flow stress of pure polycrystalline iron at $100^{\circ} \mathrm{C}$.

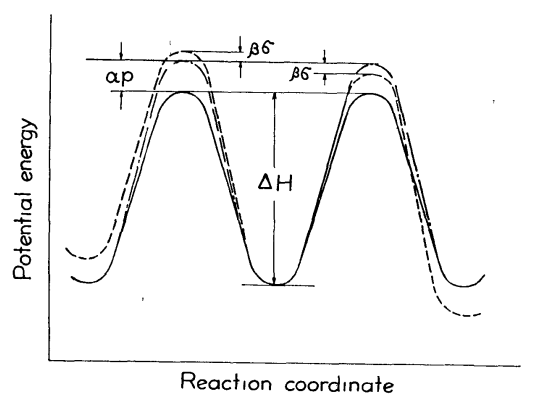

Fig. 8. Potential energy of the material subjected to both applied stress and hydrostatic pressure.

る活性化自由エネルギ $\Delta F を ~ \Delta F=\Delta H+\alpha p-\beta \sigma$ (Fig. 8参照）と扩くとき，有効反応速度すなわちひずみ速

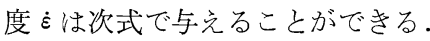

$$
\dot{\varepsilon}=Z \exp \{-(\alpha p-\beta \sigma) / k T\}
$$

ここで $Z=(k T / h) \exp (-\Delta H / k T)$ であり，kはボル ッマン定数, $T$ は絶対温度, $h$ はプランク常数, $p$ は 静水圧力であり，かつ $\beta \sigma / k T \gg 1$ を仮定した。した がって，(9)式より導かれる $\sigma=(\Delta H / \beta)+(k T / \beta) \ln (\dot{\varepsilon}$ $k T / h)+(\alpha p / \beta)$ からわかるよ5飞流動応力 $\sigma$ は静水 圧力 $p$ に線形となるが $(\alpha / \beta>0)$, 絶対温度T 亿つ ては必らずしも線形とはならない. Fig. 97および10は, 純アルミニウム $\left(99.66 \% \mathrm{Al}\right.$, 加工後 $360^{\circ} \mathrm{C}$ で $1 \mathrm{hr}$

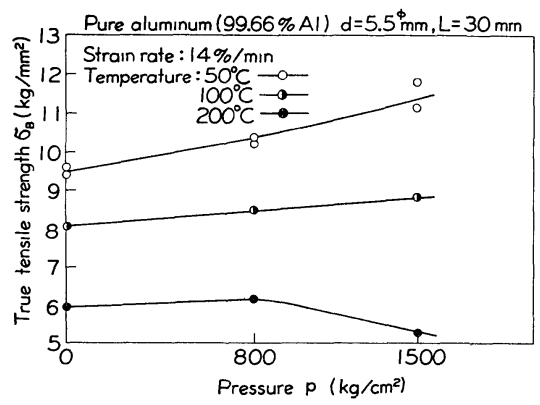

F1g. 9. Experimental dependence of confining pressure on the true tensile strength of pure polycrystalline aluminum at elevated temperatures.

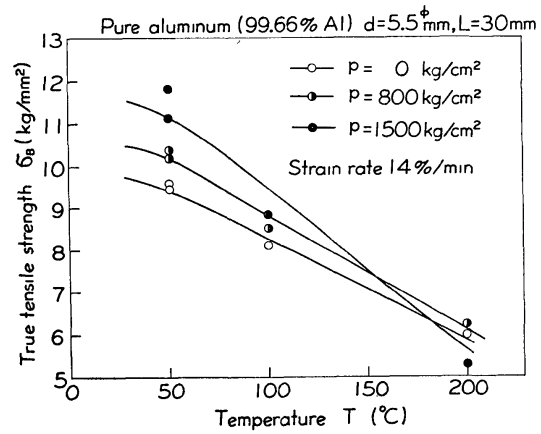

Fig. 10. Experimental dependence of temperature on the true tensile strength of pure polycrystalline aluminum under hydrostatic pressures. 
真空焼なまし）に対する引張真応力におよぼす圧力拉 よび温度の影響を示す一例である。

\section{4 静水圧応力の影響とひずみ履歴との関連性}

巨視的あるいは統計的に初期等方性を仮定しえる多 結晶金属材料に打いて通常 $\int d \varepsilon_{\imath}$ による巨視的な変形 異方性を生じ，このような暴方性も 3 で述べた結晶異 方性之同様に静水圧応力の影響を弓ける。しかしなが ら,この両者には力学的にみて明らかな違いがある. すなわ方, 局所的に存在する結晶学的異方性に静水圧 力が作用すると, 局所的に不均一变形を生じ, さらに それによって機械的な構造変化をきたすが, 外力とし ての応力に対して材料は等方的挙動を示し, 巨視的な 形状変化には何らの効果はもたない。したがって, こ のような結晶学的異方性の影響は巨視的連続体力学の 降伏条件に導入すればすでに述べた(4)式と同様のもの となる。これに対して, 巨視的異方性は静水圧力に対 して巨視的形状変化をきたし，この影響を考慮した降 伏条件は次式で与兄れよう。

$$
f\left(J_{1}, J_{2}, J_{3}, \int d \varepsilon_{\imath \jmath}\right)=F\left(\int d \varepsilon_{\imath \jmath}\right)
$$

$f$ の具体的な形としていいままでに $f=G\left(J_{1}\right) \cdot H\left(J_{2}{ }^{\prime}\right.$, $\left.J_{3}{ }^{\prime}\right)$ とする表示もあるが，これについては種々な矛盾 を含むことを指適するにとどめ，ここでは次式の代数 和形式のものを示して扰く.

$$
\left.\begin{array}{rl}
f & =G\left(J_{1}\right)+H\left(J_{2}^{\prime}, \int d \varepsilon_{\imath \jmath}\right) \\
& =C k J_{1}+\frac{1}{2} C_{\imath \jmath k l} S^{\imath \jmath} S^{k \imath}-B \varepsilon_{\imath \jmath} S^{\imath \jmath},
\end{array}\right\}
$$

ここで $C_{\imath \jmath k l}$ は変形異方性のパラメータ $A$ (スカラー) を含むひずみ履歴の影響を示す係数であり，等方性の とき(11)式右辺の第 2 項は $1 / 2 S^{\imath} S^{\imath}=J_{2}^{\prime}$ となる。 ま た， $J_{3}{ }^{\prime}=1 / 3 S^{\imath \jmath} S^{{ }^{k}} S^{k \imath}$ の影響はその影響に比べて解 析上の複雑さの大きいことを考兄て除外し（J员その ものの影響については, いわゆる Prager 形式の $f$ に ついてすでに検討される). また, $\underset{26)}{H}\left(J_{2}{ }^{\prime}, \int d \varepsilon_{\imath \jmath}\right)$ の形 については吉村および Drucker らの諸式によった。 なお，(11)式の高温クリープヘの具体的適用例について は筆者らの別報を参照されたい。

ところで，(4)式と(10)式に示したように二つの異なる 物理的意味にもとついて記述されるそれぞれの降伏条 件式は三次元応力空間に括ける幾何学的意味に特いて も相違がある。すなわち, (4)式の $J_{1}$ が $\tau_{o c t}-\sigma_{o c t}$ 面の 降伏曲線にのみ関与するのに反して, (10)式の $J_{1}$ はと くに $\pi$ 平面に平行な面, 寸なわら静水圧応力軸 $\sigma_{o c t}$ に 垂直な面に描か水る降伏曲線に関与し, b儿異方性の ため静水圧応力の影響も大きくなれば同時に $\tau_{o c t}-\sigma_{o c t}$ 面のそれにも関与する。したがって, この点からも静
水圧応力の影響と変形異方性の影響との相互関連に対 する検証は， $\tau_{o c t}-\sigma_{o c t}$ 面よりも $\pi$ 平面に平行な面上 で行なった方がよいということになる．このことにつ いては筆者らの別報を参照されたい。

Fig. 11 は(8)式に执いて $C^{\prime}=0$ (Mises の条件) 打 よび $C^{\prime}=-0.1$ と㧅た場合について $\mu=0 \sim-1$ 特 よび $\mu=0 \sim 1$ の各夾角 $30^{\circ}$ に対する範囲の降伏曲面 を $\pi$ 平面へ正射影したものを示す. 図からわかるよう に, $C^{\prime}=-0.1$ の曲線は $\mu=0 \sim-1$ の領域で Mises の円の内側に位置し， $\mu=0 \sim 1$ の領域ではそれからわ ずかに外側にはずれる．Fig.12はFig.11の関係を大気 压下の垂直応力 $\sigma$ とせん断応力 $\tau$ と関係で示したも のである.このように

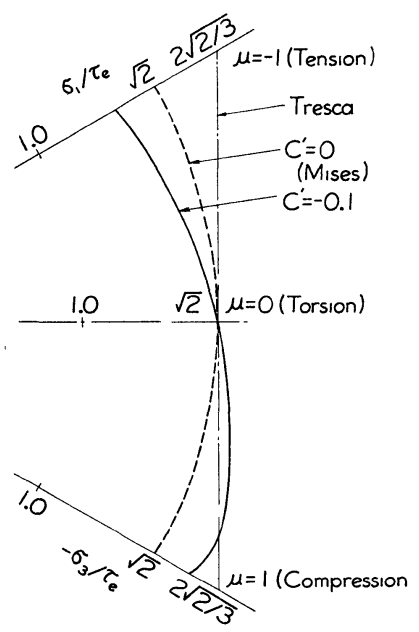

Fig. 11. Analytical representation of the effect of hydrostatic component of stresses on the yield curve on the octahedral plane at $\sigma_{o c t}=0$.

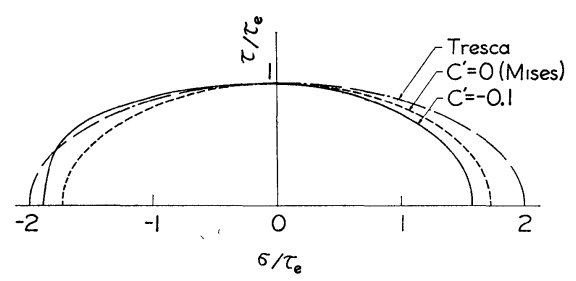

Fig. 12. Analytical representation of the effect of hydrostatic component of stresses on the $\tau$ versus $\sigma$ yield curve.

こと，とりわけFig. 12 に示すのの正負について $C^{\prime}<0$ の降伏曲線の Mises および Tresca の各降伏曲線と の相対的位置関係が異なることに注意する必要がある。 この理由は，Fig. 13 に示すように降伏曲面と $\pi$ 平面 に平行な任意の面の交線が円であっても, 応力の径路 によってみかけ上 $\pi$ 平面に描かれる軌跡は種々の形状 をとるためである。したがって，降伏に静水圧応力成 


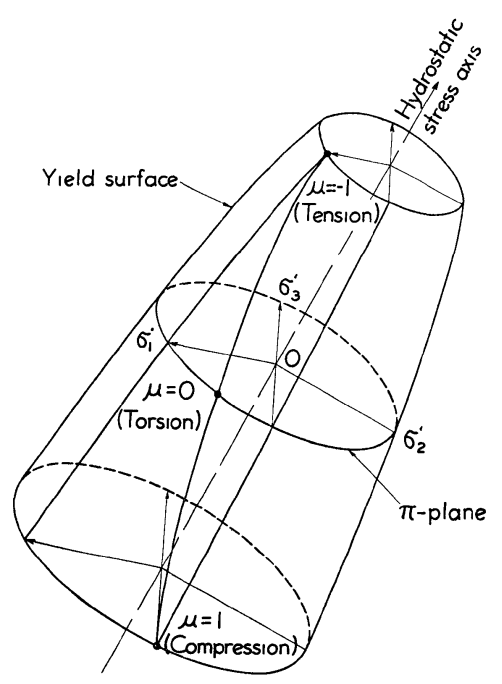

Fig. 13. Schematic exhibition of the effect of hydrostatic stress on the yield surface in three dimensional stress space.

分が関与する場合，ねじりと引張りなどの応力組合せ によって $-1 \leq \mu \leq 1$ の間の降伏曲面を $\pi$ 平面上で論 議しても，Mises の円からはずれることの説明を静水 圧応力の影響とひずみ履歴や乞の他の影響とを分離し て行ならことはでさない。したがって、ひずみ履歴の 影響, たと光ばバウシンガー効果を単独に抽出するた めには $\sigma_{o c t}=0$ の条件下での㸚じりの反転負荷などの 検証実験は適切であり, このことについては筆者らの 別報洋しい。

応力点が同一の降伏曲線上にとどまり，塑性ひずみ $\varepsilon_{\imath \jmath}{ }^{p}$ の増減汇関係しない応力増分 $d \sigma_{\imath \jmath}$ の変化は一般 に中立之呼ばれる。いま, 塑性的体積変化は零, 拉上 び $d \varepsilon_{\imath \jmath}{ }^{p}$ の主軸は主応力軸に一致すると仮定すると次 式の流れの式が導かれる。

$$
d \varepsilon_{\imath \jmath}{ }^{p}=h \frac{\partial g}{\partial \sigma_{\imath \jmath}} d f
$$

ここで, $g$ (そ机は通常 $f$ と等置されるもので塑性ポ テンシャルと呼ばれる）拉よび $h$ は $J_{2}^{\prime}, J_{3}{ }^{\prime}$ のスカラ 一関数であり, また $\int d \varepsilon_{\imath}$ の関数でも市る。ところが, (4)式の降伏条件注いてては，等降伏曲線上で $d \sigma_{\imath}$, の 変化に対して $\varepsilon_{\imath j}{ }^{p}$ の增減を执こさないという条件は $d f=0$ と抢くことと等価ではない.なぜならば，(12)式 より

$$
d f=\frac{\partial f}{\partial \sigma_{\imath \jmath}} d \sigma_{\imath \jmath}=\frac{\partial F}{\partial J_{1}} \frac{\partial J_{1}}{\partial \sigma_{\imath \jmath}} d \sigma_{\imath \jmath}
$$

となり， $F=F\left(J_{1}\right)$ であるかぎり右辺は一般に零之は ならず，それが零となるのは $\left(\partial F / \partial J_{1}\right)=0$ あるいは $\left(\partial J_{1} / \partial \sigma_{\imath \jmath}\right)=0$ のときのみであり, これはいわゆる $\pi$ 平面に平行な面上で $d \sigma_{\imath}$ の変化がある場合飞相当し, その他の一般的な $d \sigma_{\imath \jmath}$ の変化では $\left(\partial F / \partial J_{1}\right) \neq 0$, $\left(\partial J_{1} / \partial \sigma_{\imath \jmath}\right) \neq 0$ である.したがって，(4) 式の降伏条件 は中立負荷の状態に対して(12)式の流れの式はそのまま 適用できないことに注意すべさである。しかし，静水 圧応力成分が材料の力学的挙動他あまり影響を与えな いような構造変化が拈こる範囲では $\left(\partial F / \partial J_{1}\right)=0$ と なって流れの式は近似的に仮定できることになる。こ の近似としての仮定がなりたつのは一般に塑性変形の 小さい領域のみで, 塑性変形が進展するにしたがい, あるいは静水压応力成分の影響が増大するにしたがっ てこの仮定は適用されず持のづから適用限界が岗るは ずである。他方，(11)式の降伏条件に対する流れの式の 適用は，F以 $J_{1}$ を含まないことから中立負荷の条件 $d f=0$ は形式的に成立する.ここで，(12)式の流れの式 を導くための塑性的体積不変則について形式的には $\dot{\varepsilon}_{k k} \neq 0(C \neq 0$ のとき) となるが，実際問題として塑性 的体積不変則を論ずるが゙りとれは成立するとして差 支光ない.

\section{5 不安定変形および破断におよばす静水圧力の影} 響

不安定変形（引張くびれ）の問題は材料の延性を評 価するら党で重要な条件の一つであり, 塑性加工の分 野では加工限界の条件として不安定変形の開始をでき るだけ避けることを通じて材料の延性を增すことが経 験的行なわれてきた。したがって，高温行括ける不 安定変形の問題も同様の意義をもつ之考光て上い. 軸 引張り（その応力を $\sigma$, 軸ひずみをととする）に打け る不安定変形開始の条件は, 上く知られている上5以 $d \sigma / d \varepsilon=\sigma$ で与えられるが，これを多軸応力状態に拡 張した場合は

$$
d \bar{\sigma} / d \bar{\varepsilon}=\bar{\sigma} / s
$$

と拈き, $s=1$ が単軸引張り, $s>1$ が引張延性の増大, $s<1$ が引張延性の減少の条件として説明が行なわれ ている。 この場合注意すべさことがらは，(14)式があく まで塑性降伏に対して静水圧応力は影響しないという ことを前提として，その仮定のもと飞不安定変形にお よ汸す多軸負荷 (二軸特よび三軸) の影響が論ぜられ ているといらことである。しかし， 3 蛒よび 4 で述べ たようにひずみ履歴の影響と関連して少なくとも不安 定変形域に和忊る塑性流動応力対して静水圧応力の 影響があらわれて静水圧力の増大にともない破断伸び が増大寸る。したがって，(14)式からは静水圧力下にお ける軸引張延性の増大を説明することができない．

では，静水圧力下に括活る金属材料の延性の増大は 少なくとも現象論のう兄ではどのように説明されるの か，それを以下に簡単注述べてみることにする。.(8)式 にるとづく相当応力 $\bar{\sigma}$ は次式で与えられる。

$$
\frac{1}{6}\left\{\left(\sigma_{1}-\sigma_{2}\right)^{2}+\left(\sigma_{2}-\sigma_{3}\right)^{2}+\left(\sigma_{3}-\sigma_{1}\right)^{2}\right\}
$$


$\left.\begin{array}{l}\quad=\lambda^{\prime 2} \bar{\sigma}^{2}+\lambda^{\prime} C^{\prime} \bar{\sigma}\left(\sigma_{1}+\sigma_{2}+\sigma_{3}\right) \\ \text { ただし } \\ \quad \lambda^{\prime}=\frac{1}{2}\left(-C^{\prime}+\sqrt{C^{\prime 2}+\frac{4}{3}}\right)\end{array}\right\}$ (15) $d \bar{\sigma} / d \bar{\varepsilon}=\bar{\sigma}(大$ 気圧下に拈ける単軸引張りの 条件）に代入すると次式の関係式がえられ る.

$$
\left.\begin{array}{rl}
\quad d \sigma / d \varepsilon=\sigma / S_{p} \\
S_{p}= & -\frac{C^{\prime}}{2 \lambda^{\prime}}+\frac{1}{2 \lambda^{\prime 2}} \boldsymbol{\Phi}^{-1 / 2}\left\{C^{\prime 2}\left(1-3 \frac{p}{\sigma}\right)\right. \\
& \left.\quad+\frac{4}{3}\right\} /\left\{-\frac{C^{\prime}}{2 \lambda^{\prime}}\left(1-3 \frac{p}{\sigma}\right)+\frac{1}{2} \boldsymbol{\Phi}^{1 / 2}\right\}
\end{array}\right\}
$$

(16)式から明らかなように $p=0$ (大気圧) のとき $C^{\prime} の$ 值に無関係に（C'=0 をらくむ） $S_{p}=1$ であり，また $C^{\prime}=0$ (Mises の降伏条件) のときは $p / \sigma$ に無関係に $S_{p}=1$ となる. Fig. 14 は $S_{p}$ が $p / \sigma$ によっでのよ らに変化するかを示した解析例であり，図からわかる ように $p / \sigma$ の増大にともない $S_{p}$ も単調に増加して 材料の延性がますものと考えられる. しかし, この解 析例にも又られるように, $S_{p}$ は $p / \sigma$ の増加にともな

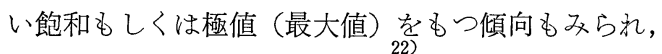
このことは最近になって西原らによる高温下に拈ける 三軸応力実験 (温度最高 $600^{\circ} \mathrm{C}$, 最高圧力 $5000 \mathrm{~kg} /$ $\mathrm{cm}^{2}$, 圧力媒体はアルゴン・ガス) において観察され た。すなわち, 金属材料の延性に和よぼす圧力と温度 の依存を, (1)圧力, 温度の増加にともない除々に延性

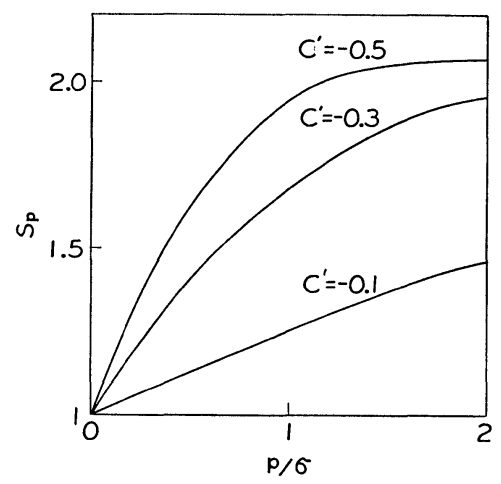

Fig. 14. Analytical dependence of combined confining pressure on plastic elongation at which the necking occurs.

*418)式の降伏条件を用いるときは一般に流れの式は成立しないが， 静水压力 (一定) のもとての軸引張りにおける $J_{1}=\sigma_{k k}$ は実験 中大きく変化しないので $F \cong 一$ 定とおくととがてき，との場合 の $\bar{\varepsilon}$ は $\bar{\varepsilon}=\varepsilon$ となる。
(M. Nishihara etal)

(M. Nishihara etal)

$20 \sim 30 \%$ ○ 60 70\%

$\begin{array}{ll}30 \sim 40 & : 70 \sim 80 \\ 40 \sim 50 & : 80 \sim 90\end{array}$

\begin{tabular}{l}
$40 \sim 50$ \\
\hline
\end{tabular}

(a)

Magnesium alloy

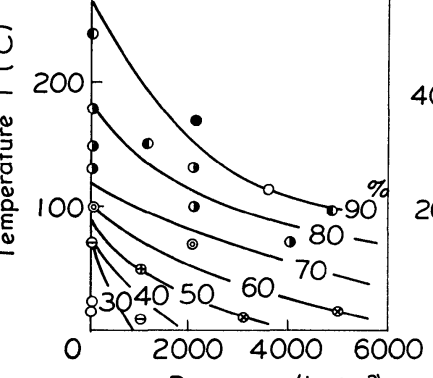

Pressure $p\left(\mathrm{~kg} / \mathrm{cm}^{2}\right)$

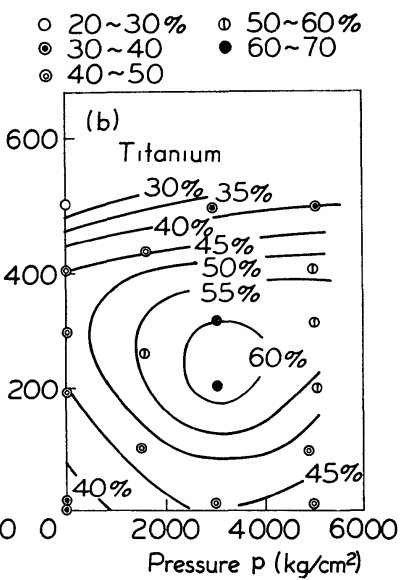

Fig. 15. Experimental representation of the effects of both temperature and hydrostatic pressure on fracture elongation of magnesium alloy and titanium.

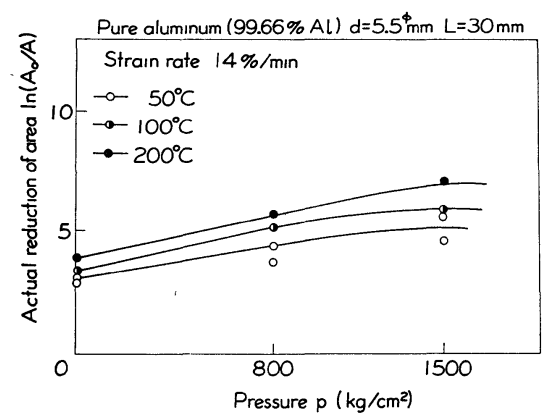

Fig. 16. Experimental representation of the effect of confining pressure on reduction of area of pure polycrystallıne aluminum.

がます場合，(2)ある压力，温度で極大にある場合，特 よび(3)范る圧力, 温度で急にぜい性から延性に変わる 場合の三つに分類 し， Fig. 15 は，(1)の場合の一例之 してマグネシウム合金を(2)の場合の一例としてチタニ ウムのそれぞれの引張り等伸び線図を示す。図からわ かるように, Fig. 15 (b) の場合, $3000 \mathrm{~kg} / \mathrm{cm}^{2}, 300^{\circ} \mathrm{C}$ で最大の伸びを示す。また，Fig. 16) は筆者らによる 純アルミニウム $\left(99.66 \% \mathrm{Al}\right.$, 加工後 $900^{\circ} \mathrm{C}$ で $1 \mathrm{hr}$ 真空焼なまし）の高温引張破断ねじり（真ひずみ）飞 扣よぼす静水圧力の影響を示し, 実験の範囲内では(1) の場合に相当する。

\section{6 クリープおよびクリープ破断におよばす静水圧 \\ 応力の影響}

多軸応力下の高温クリープについても，巨視的立場 ではもっぱら連続体力学での塑性理論の基礎理論をそ のまま導入することが多い。この導入のなかでとくに 最近疑問視さ礼ているのが以上述べた静水圧応力成 分の影響である. 最近における高温高圧力下のクリー 


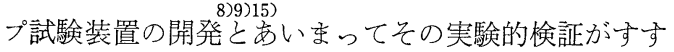
み, 最近では比較的変形量の大きい定常クリープな どでは常温および高温を問わず静水圧応力の影響が応 力依存性を論ずるう壳で不可避的な因子であることが 泀ぼ明らかになってきた。

では, クリープ速度に抢よぼす静水圧応力の影響が いままで述べてきた静的塑性流動応力におよぼす影響 に比べて大きい原因は何によるのか，またそれとの関 連はどうあるのか, さらに温度执よびひずみ履歴との 関連がどうあるのか，などの質問が発せられるが，そ れらについて以下簡単に述べてみよう。まず, 連続体 力学的解釈について, クリープの支配機構が拡散など り熱活性化エネルギに依存しないと思われる常温クリ 一プについて考えてみることにする．いま， Fig. 17

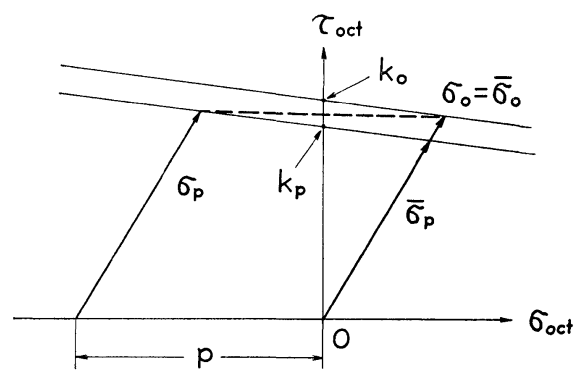

Fig. 17. Schematic exhibition of apparant decrease in creep stress of the material subjected to combined confining pressure.

のモデルのように降伏曲面が 静水圧応力軸 $\sigma_{o c t}$ に対 して傾いているとし, 大気圧のもとで $\sigma_{0}$ なる単軸引張 応力を加えたとき, その材料の降伏状態は, $k$ の值が $k_{0}=$ 一定之ある降伏曲面上にあると考える.さらに, 静水圧力 $p$ のもとでの軸引張応力 $\sigma_{p}$ (この図では $\sigma_{p}$ $\left.=\sigma_{0}\right)$ を加えた状態での $k$ の值は $k_{p}=$ 一定であるとす る. 前者の場合の $k$ は, (8)式に $J_{2}{ }^{\prime}=\sigma_{0}^{2} / 3, J_{1}=\sigma_{0}, k$ $=k_{0}$ を代入して $k_{0}=\lambda^{\prime} \sigma_{0}$, 後者の場合の $k$ は, $J_{2}^{\prime}=$ $\sigma_{p}^{2} / 3, J_{1}=\sigma_{p}-3 p, k=k_{p}$ を代入して $k_{p}=(1 / 2)\left[-C^{\prime}\right.$ $\left.\{1-3(p / \sigma)\}+\sqrt{C^{\prime 2}\left\{1-3(p / \sigma)^{2}+(4 / 3)\right\}}\right] \sigma_{p}$ で与光 られる。ここで光は(15)式に示したと和りである。した がって, $k_{p}$ に対応した大気圧下での単軸引張応力 $\bar{\sigma}_{p}$ は， (15)式を導いたと同様, $\bar{\sigma}_{p}=(3 / 2)\left\{C^{\prime}+\sqrt{C^{\prime 2}+(4 / 3)}\right\} k_{p}$ で与兄られて明らかに $C^{\prime}=0$ を除いて $\bar{\sigma}_{p}<\sigma_{p}$ である。 したがって, 静水圧力 $p$ のもとでの軸引張クリープ速 度 $\dot{\varepsilon}_{p}$ と大気圧下に拈けるそれ $\dot{\varepsilon}_{0}$ との比は次式で与 えられる。

$$
\begin{aligned}
\frac{\dot{\varepsilon}_{p}}{\varepsilon_{0}}= & \left(\frac{\bar{\sigma}_{p}}{\bar{\sigma}_{0}}\right)^{n}=\lambda^{n}\left\{-C^{\prime}\left(1-3 \frac{p}{\sigma}\right)\right. \\
& \left.+\sqrt{C^{\prime 2}\left(1-3 \frac{p}{\sigma}\right)^{2}+\frac{4}{3}}\right\}^{n}
\end{aligned}
$$

$$
\lambda=\frac{3}{4}\left\{C^{\prime}+\sqrt{C^{\prime 2}+\frac{4}{3}}\right\}
$$

ここでクリープ速度は定常クリープ速度を対象とし， そのクリープ速度式を $\dot{\varepsilon}=\alpha \sigma^{n} \quad(\alpha, n$ は温度一定の とき定数）を用いた。同様に単純ねじりクリープ速度 の場合についても静水圧力执よび大気圧下での各せん 断クリープ速度を $\dot{\gamma}_{p}, \dot{\gamma}_{o}$ とおくと， $\dot{\gamma}_{p} / \dot{\gamma}_{o}$ は(8)式にも とづく場合は，

$$
\frac{\dot{\gamma}_{p}}{\dot{\gamma}_{o}}=\left(\frac{1}{2}\right)^{n}\left\{3 C^{\prime}\left(\frac{p}{\tau}\right)+\sqrt{9 C^{\prime 2}\left(\frac{p}{\tau}\right)^{2}+4}\right\}^{n} \text { (18) }
$$

でまた(7)式にもとづく場合は

$$
\left(\frac{\dot{\gamma}_{p}}{\dot{\gamma}_{o}}\right)^{\frac{4}{n}}-3 C\left(\frac{p}{\tau}\right)\left(\frac{\dot{\gamma}_{p}}{\dot{\gamma}_{o}}\right)^{\frac{3}{n}}+9 D\left(\frac{p}{\tau}\right)^{2}\left(\frac{\dot{\gamma}_{p}}{\dot{\gamma}_{o}}\right)^{\frac{2}{n}}=1
$$

の高次の方程式で与えられる。ここでては単純ねじり 応力である. Fig. 18 は, 純亜鉛 $(99.91 \% \mathrm{Zn})$ につ いて温度 $15^{\circ} \mathrm{C}$ (油中) で $\tau=3.5 \mathrm{~kg} / \mathrm{mm}^{2}$ 一定下で大 気圧から静水圧力を段階的に変化させた場合のねじり クリープ曲線を大気圧下のそれと対比して示したもの である。な拈，ここでは定常域からの部分のみを示し， 遷移クリープ段階は省略されている. Fig. $19^{6)}$ は Fig. 18の結果を(19)式の表示にしたがって示したものであり， 実験結果は同じくせん断ひずみ $r=30 〜 40 \%$ に拈る

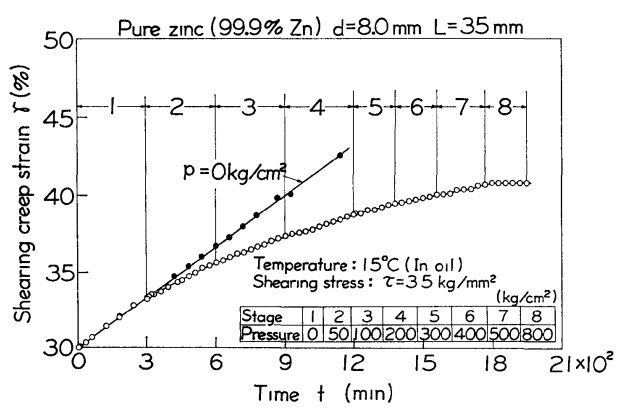

Fig. 18 Experimental tensile creep curve of pure polycrystalline $z 1 n c$ subjected to stepwise eleva. tion of combined hydrostatic pressure at $15^{\circ} \mathrm{C}$.

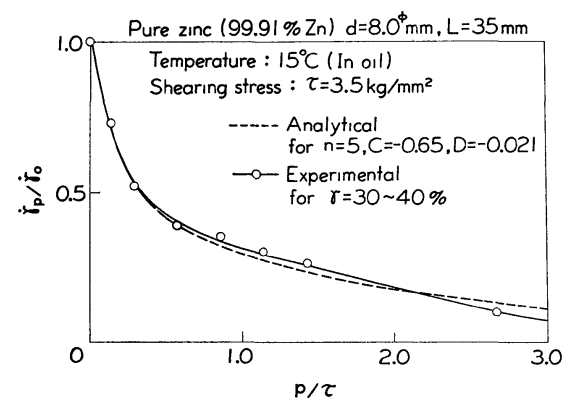

Fig. 19. Experimental and analytical variations of shearing creep rate of pure polycrystalline zinc at $15^{\circ} \mathrm{C}$ in accordance with elevation of combined hydrostatic pressure. 
同一材料の静的叔じり試験におけ子る静水圧力の影響度 を示すパラメータC就よびDの值（前述の Fig. 5 参 照）を用いて(19)式によって計算した解析結果ときわめ てよい一致を示すことがわかる。このことは純アルミ ニウムや純鉄に対する静水圧力下の常温引張クリープ 実験結果に打いて子確認することができる。したがっ て, 静水圧力重畳負荷に上る常温クリープ速度の減少 効果はクリープ応力のみかけ上の減少に上るものであ り, その効果は静的塑性流動によるものと同程度であ るとみなしてほとんど誤りはないと思われる。

ついで, 常温より温度が高くなった場合, たとえば $T_{m} / 2$ (ここで $T_{m}$ は材料の融点) 近傍の温度での高 温クリープに対して 静水圧力の影響はどうなるか. Fig. $20^{9}$ は純鉄 $\left(99.97 \% \mathrm{Fe}\right.$, 加工後 $900^{\circ} \mathrm{C}, 1 \mathrm{hr}$ で

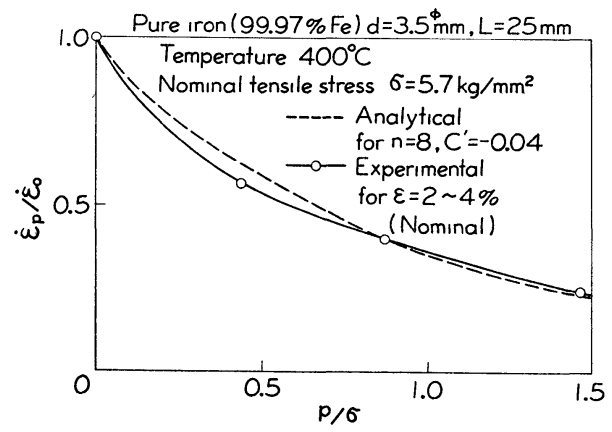

Fig. 20. Experimental and analytical variations of tensile creep rate of pure polycrystalline iron at $400^{\circ} \mathrm{C}$ with elevation of combined confining pressure.

真空坴なおし）の温度 $400^{\circ} \mathrm{C}\left(T / T_{m}=0.6\right)$ に和ける 定常クリープ段階での引張クリープ速度におよ持す静 水圧力（圧力媒体は拡散油）の影響を示す実験例を Fig. 19 と同様の表示によって示したるのである. 図 から実験点は, (17)式で $C^{\prime}=-0.04, n=8$ と和いて計 算した解析結果とかなりよく一致することがわかる. しかし、ここで注目しなければならないことは，この 場合の $C^{\prime}$ の值が同材料の温度 $400^{\circ} \mathrm{C}$ 飞括沙る静的引 張塑性流動応力に扣よぼす静水圧力の影響を示す $C^{\prime}$ の值 $C^{\prime}=-0.002$ (伸び $\varepsilon=5 \%$ に抢ける）よりはるか に大きくなることである。このことを説明するために は, 静水圧力負荷によるクリープ応力のみか子上の減 少効果以外飞高温クリープに和ける原子空孔の拡散な どのそれ自体のもつ圧力效果を付加的に考慮する必要 があるう。いま，Nabarroによって提案された原子空 孔の拡散クリープ理論を用いると, 静水圧力かのもと で軸引張応力のを負荷する場合の軸方向クリープ速度 をは次式で与克ることがでさる。

$$
\dot{\varepsilon}=\frac{16 \alpha D}{\pi d^{2}} e-\beta \Omega_{v p / k T}\left(e \beta \Omega_{v^{\sigma}} / k T-1\right)
$$

ここで, $d$ は結晶粒大いさのオーダ， $\alpha \approx 1 ， D$ は自

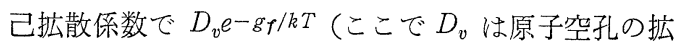
散係数, $g_{f}$ はその形成エネルギ, $k T$ は通常の意味の もの）飞等しく， $\Omega_{v}$ は原子空孔の体積で注涪 $b^{3}(b$ は原子の格子間距離）飞等しい。したがって(20)式より $\dot{\varepsilon}_{p} / \dot{\varepsilon}_{o}$ は次式で与兄られる.

$$
\dot{\varepsilon}_{p} / \varepsilon_{o}=\left(D_{p} / D_{o}\right) \exp \left(-\beta \Omega_{v} p / k T\right)
$$

ここで $D_{o}, D_{p}$ は大気圧および静水圧力下での自己桩 散係数である. 類似の式は Butcher らによって別の

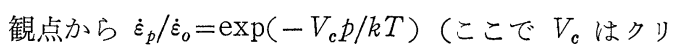
ープの活性化体積であり，たと党ば,アアルミニウムの 高温タリープに対して $V_{c} \approx(4 / 3) \Omega_{v}^{32)}$ である) なる関 係式が誘導されている。ここで $D_{p} / D_{o}=1, \beta \Omega_{v}=V_{c}$ と抢いたとき形式的に(21)式と一致する。いずれにせよ， 静水圧力は高温クリープの場合, クリープ機構自体か ら考光てクリープ速度を減少させる付加的効果をるつ ことは明らかである。

高温クリープ破断時間に打よぼす静水圧力の影響に ついては, いま破断時間 $t_{r}$ と最小クリープ速度 $\dot{\varepsilon}_{\min }$ との間に $t_{r} \cdot \dot{\varepsilon}_{\mathrm{m} \text { In }}=$ 一定の関係がなりたつるのとする 之, 同一のののもとので大気圧就よび静水圧力 $p$ のも とでの引張クリープ破断時間 $\left(t_{r}\right)_{0}$ と $\left(t_{r}\right)_{p}$ との比は (17)式より

$$
\begin{aligned}
\frac{\left(t_{r}\right)_{p}}{\left(t_{r}\right)_{o}}= & \frac{\left(\dot{\varepsilon}_{\min }\right)_{o}}{\left(\dot{\varepsilon}_{\min }\right)_{p}}=\lambda^{-n}\left\{-C^{\prime}\left(1-3 \frac{p}{\sigma}\right)\right. \\
& \left.+\sqrt{C^{\prime 2}\left(1-3 \frac{p}{\sigma}\right)^{2}+\frac{4}{3}}\right\}^{-n}
\end{aligned}
$$

で与えられる。ここで入は式(17)に示したと拉りである. Fig. 21 は, Hull らの純銅 (99.8\%) 飞対する静水圧 $99.8 \% \mathrm{Cu}$ (D. Hull and D.E.Rımmer)

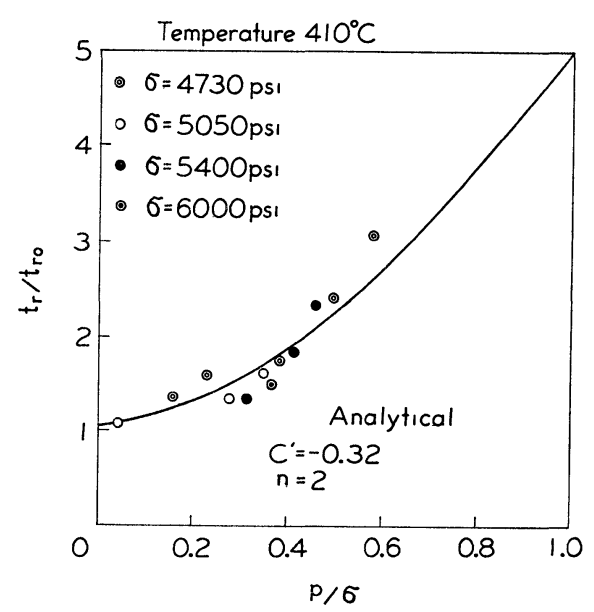

Fig. 21. Experimental and analytical representations of the effect of combined hydrostatic pressure on tensile creep rupture time of pure polycrystalline cupper at $410^{\circ} \mathrm{C}$.

*5 自己昖散係数が一般に静水圧力に影響される ${ }^{33}$ のて厳密には $D_{p} /$ $D_{o}=1$ とはならない. 
力下（圧力媒体はアルゴン・ガス）に和ける温度 410 ${ }^{\circ} \mathrm{C}$ での引張クリープ破断実験結果を(22)式の表示にした がって示したものであり， $C^{\prime}=-0.32 ， n=2$ と执い た場合の計算結果はよく実験結果の傾向を示すものと 考えられる、なお，高温クリープ破壞に拉よぼす静水 圧応力成分の影響については，その破壊法則を定式化 するらえでひずみ履歴や応力分布の影響などとならん で重要な因子と考えられるようになり，最近では内圧 円筒管の高温クリープ破壊や切欠さクリープ破壞の応 力条件に有効にとり入れられるようになった。たとえ ば，二軸応力状態に执ける破断寿命 $\left(t_{r}\right)_{b \imath}$ への静水圧 応力成分 $\sigma_{m}=\sigma_{x}+\sigma_{y}$ の寄与は, 一軸応力状態に护怕 る破断寿命 $\left(t_{r}\right)_{u n \imath}$ との比較のうえで(22)式と同様の形 で次式で与えられる。

$$
\begin{aligned}
& \frac{\left(t_{r}\right)_{b \imath}}{\left(t_{r}\right)_{u n \imath}=}\left[\lambda \left\{-(1+A) C^{\prime}\right.\right. \\
&\left.\left.+\sqrt{(1+A)^{2} C^{\prime 2}+\frac{4}{3}\left(A^{2}-A+1\right)}\right\}\right] \\
&\left.\sqrt{A^{2}-A+1}\right]^{-n} \\
&= {\left[\lambda\left\{-C^{\prime}\left(\frac{\sigma_{m}}{\bar{\sigma}}\right)+\sqrt{C^{\prime 2}\left(\frac{\sigma_{m}}{\bar{\sigma}}\right)^{2}+\frac{4}{3}}\right\}\right]^{-n} }
\end{aligned}
$$

ここで, 二軸応力状態に和ける $\sigma_{x}$ と $\sigma_{y}$ との組合せ, すなわち応力比 $A=\sigma_{y} / \sigma_{x}$ は Mises 基準による相当 応力 $\bar{\sigma}$ にしたがうものである。したがって， $\bar{\sigma}=$ $\sqrt{A^{2}-A+1} \sigma_{x}$ であり, 静水圧応力成分 $\sigma_{m}$ は同一の $\bar{\sigma}$ のもとで $A$ ともに $\sigma_{m}=\left\{(A+1) / \sqrt{A^{2}+A-1}\right\} \bar{\sigma}$ にしたがって変化する. Fig. 22 には $\sigma_{m} / \bar{\sigma}$ と $A$ との 関係を示し, さらに $A$ の変動に対する破断寿命 $\left(t_{r}\right)_{b r} /$

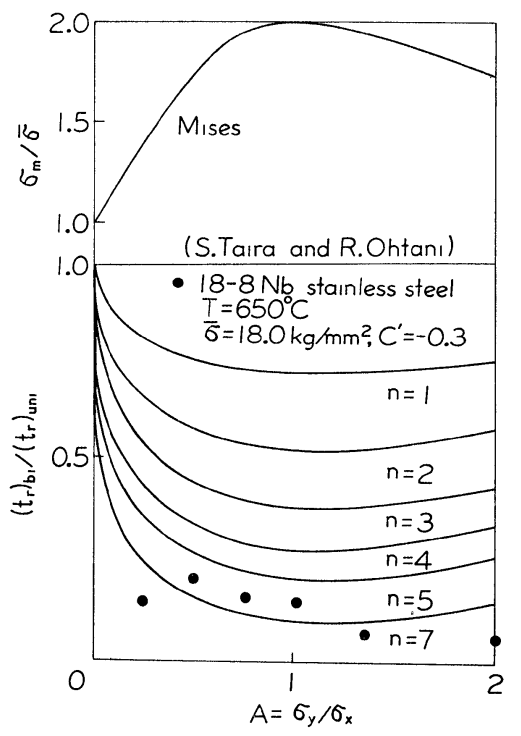

Fig. 22. Changes of $\sigma_{m} / \bar{\sigma}$ and $\left(t_{r}\right)_{b r} /\left(t_{r}\right)_{u n i}$ with stress ratio $A$ under constant equivalent stress $\bar{\sigma}$. $\left(t_{r}\right)_{u n \imath}$ の変化を $C^{\prime}=-0.3$ として，nの 1 から 7 ま での值に対してそれぞれ(23)式にもとついて計算した結 果を示す. 図中の黑丸点は大谷の 18-8 Nb ステンレ 又鋼の薄肉円筒の温度 $650^{\circ} \mathrm{C}$, 相当応力 (Mises 基準) $\bar{\sigma}=18.0 \mathrm{~kg} / \mathrm{mm}^{2}$ 一定下に打辇る内圧一軸引張組合せ クリープ破断実験結果を整理しなおしてプロットした ものであり，Aによる破断寿命の相違の一因を説明づ けることができる。

以上のよ5に, 静水圧応力成合は高温クリープ変形 はむろんのこと破断に至るまで強く影響し，高い静水 圧応力成分の発生する状態ではこれを無視することは できないであろう。したがって，それは，クラックの 先端付近とか, 各種の析出物や介存物などによる応力 集中個所ではとくに顕著になり，さらにクラックの多 数発生した破断近傍などではとくに静水圧応力の影響 が強くなる傾向にあるものと思われる。

\section{7 むす び}

以上は，おもに高温に和ける多結晶金属材料の塑性 法則に関する最近の研究として, クリープおよびクリ 一プ破断を含めて最近話題の多い静水圧応力およびひ ずみ履歴の影響に関する解析的および実験的研究の現 状を筆者らの研究結果を中心として展望を試みた。な 拉，多軸応力下の高温クリープにおよぼすひずみ履歴 の影響，とりわけ材料の变形異方性および，バウシン ガー効果の影響については紙面の関係上割愛し, 別報 にゆずることにした。これらの塑性法則については， さらにひずみ速度の影響, 応力および温度変動の影響 (応力および温度履歴や thermo-mechanical coupling) などの側面を通じて定式化が望まれるが，ここではま ず高温に拉ける単純なひずみ経路をもつ静的引張りあ るいは単純礼じり执よびそれらのクリープに関する巨 視的塑性法則を, 静水圧応力掞よびひずみ履歴の影響 を考慮した三軸応力空間に执ける塑性流動和よびクリ ープ挙動のなかに正しく位置付けることが大切である ことを強調したつもりである。とりわけ，高温に打け る塑性流動和よびクリープに抢よぼす静水圧応力の影 響が不安定変形域などの大変形領域沶よびクリープと その破断に対して無視できないことを指摘し，したが って静水圧応力の影響は材料のひずみ履歴の影響と密 接に関連することを指摘した。

\section{参 考 文 献}

1) IUTAM-Symp. on High Speed Computing of Elastic Structures (1970-8, Belgium).

2) たとえば, McMahon, C. J , Jr, “Microplastıcity,” (1968) Interscience Pub., New York

3）たと党ば, Proc. IUTAM-Symp. “Mechanics of Generalized Continua” (1968) Springer-Verlag, Berlin

(11)


4) Hu, L. W., and K.D. Pae, J. Franklin Inst., 264, 491 (1963).

5) 大南正瑛，材料， 16, 161 (1967).

6) 大南正瑛, 元家勝彦, Proc. 12 th Jap. Cong. Mat. Res., 78 (1969)；機械学会第44期全国大会講演会前刷 No. 162, p. 119 (1966-10)，機械学会論文集に投稿中；第14回材 料研究連合講演会前刷, p. 147 (1970-9)，材料に投稿中。

7) 大南正瑛, Proc. 13 th Jap. Cong. Mat. Res., 126 (1970).

8）平 修二, 大谷隆一注か, 機械学会第17期通常総会講演 会前刷, p. 57 (1968-5).

9）大南正䒨，元家勝彦，山蔭哲郎，材料， 20, 395 (1971)

10）たとえば, Proc. Joint. Inter. Conf. on Creep (1963. New York) に执ける A.E. Johnson, W. N. Findley, V.S. Namentnikov, I. Finnie の各論文.

11）たとえば，平 修二編 “金属材料の高温強度” (1968), 養賢堂に大谷隆一（単軸和よび多軸応力下のクリープ強 度）扣よび大南正瑛（変動応力・温度変動下のクリー プ）の解説がある.

12）平 修二, 中西英介, 金属学会会報, 6-4, 267 (1967).

13) 大南正䒨, 元家勝彦, 吉田信夫, 材料, 18, 226(1969); 大南正瑛, 吉田信夫, Proc. 12 th Jap. Cong. Mat. Res., 81 (1969).

14) Hull, D., and E. Rimmer, Phil, Mag., 4, 673 (1954).

15) Butcher. B.M, and A. L. Ruoff. J App. phys., 32, 2036 (1961).

16) Davidson, J.C., J.C. Uy, and A.P. Lee. Trans. AIME, 233, 820 (1965).

17）斉藤進六, 塑性と加工, 69, 518 (1966).

18) Williams, M. L., and R.A. Schapery, Inter. J. Fracture Mech., 1, 64 (1965).

19）Hill, R., “塑性学” (䈍津活か訳), p. 19 (1953) 倍風館

20) Hu, L. W., Proc. 2 nd Symp. on Naval Structural Mechanıcs, "Plasticity.” p. 194 (1960) Pergamon

21) Crossland, B., and W.H. Dearden, Proc. Inst. Mech. Engr., 172, 809 (1958).

22）西原正夫, 田中吉之助, 山本俊二, 山口喜弘, 材料, $\mathbf{1 6}$, 169 (1967).
23）田中吉之助, 中島 稔, Proc, 10 th Jap. Cong. Test. Mat., 68 (1967).

24) Glasstone, S. G., K. J. Laidler, and H. Eyring, “The Theory of Rate Process,” (1941) McGraw-Hill

25）元家勝彦, Sunho Kang, 大南正瑛, 遠藤外雄, Memoirs of. Res. Inst. Science and Engg., Ritsumeıkan Univ., 14, 97 (1965)；機械学会第 43 期通常総会講演会前刷, No. 147, p. 69 (1966).

26）吉村慶丸，たとえば “塑性力学”（応用力学 講座 11) （1964）共立出版

27) Drucker, C. D., and F. Edelman, J. Franklin Inst., 252, 581 (1951).

28) Hoggart, J.S., Proc. 2nd Tewksbury Symp., "Fracture," p. 155 (1969) Butterworths

29) Swift, H.W., J. Mech. Phys. Solids., 1, 1 (1952).

30）西原正夫, 機械学会誌, 73, 1246 (1970) ; Science and Engng, Review of Doshisha Univ., 9-1, 41 (1968).

31) Nabarro, F.R. N., " Report of Conference on Strength of Solids," p 75 (1948).

32) Ruoff, A. L., Proc. 1 st Inter. Conf. on physics of Solıds at High Pressure, "Physics of Solids at High Pressure,” p. 379 (1965) Academic Press

33）たとえば, MM. M. Beyeler and Y. Adda, 上同, p. 349.

34) Monkman, F.C., and N. J. Grant, Proc. ASTM, 56, 834 (1956).

35）大谷隆一, 材料, 19, 160 (1970).

36）大南正瑛，阿波屋義照，元家勝彦，高田晄男，材料， 20, 361 (1971).

37) Taira, S., and R. Ohtani, IUTAM Symp. (East Kilbride, 1968) “Thermoinelast1city" (ed. by B. A. Boley, 1970), p. 297 (Springer-Verlag. )

38）大南正瑛, 元家勝彦, 吉田信夫, Memoirs of Res. Inst., R.tsumeikan Univ., 15, 83 (1966); 機械学会第 44 期 全国大会前刷, No.161, p 113 (1966) ; 材料, 18, 226 (1969); 大南正瑛, 吉田信夫, Proc. 12 th Jap. Cong. Mat. Res., 81 (1969). 